태양전지 CIGS용 Mo 후면전극의 전기 저항에 관한 연구

김강삼, 조용기

한국생산기술연구원, 뿌리산업기술연구본부, 열·표면연구그룹

\title{
The Study on the Electrical Resistivity for Mo Back Contacts Film of CIGS Solar Cell
}

\author{
Gang Sam Kim, Yong ki Cho
}

Korea Institute of Industrial Technology, Production Technology R\&D Department,

Heat Treatment and Surface Engineering R\&D Group, Korea

(Received December 2, 2011 ; revised December 27, 2011 ; accepted December 30, 2011)

\begin{abstract}
The Molybedenium thin film is generally used on back contact material of CIGS solar cell due to low electrical resistivity and stable thermal expansion coefficient. The Mo thin films deposited on si wafer by the magnetron sputtering method. The research focused on the variation of electrical resistivity of films which deposited with various working pressure at the target power of $2.0 \mathrm{~kW}(8.4 \mathrm{~W} /)$. The lowest resistivity of Mo thin film showed $9.0 \mu \mathrm{O}-\mathrm{cm}$ at pressure of $1.5 \mathrm{~m}$ Torr. However, working pressure increasing up to 50 mTorr, resistivities were highly increased. The results showed that the conductivity of Mo films depended on growing structures and defects in deposition process. Surface morphology, porosity, grain size, oxidation, and bonding structures were analysed by SEM, AFM, spectroscopic ellipsometry (SE), XRD, and XPS.

Keywords: Mo films, CIGS, Sputtering, Electrical resistivity, Porosity, Oxidation
\end{abstract}

\section{1. 서 론}

$\mathrm{Mo}$ 박막은 $500^{\circ} \mathrm{C}$ 이상의 고온에서 $\mathrm{CIS}$ 및 $\mathrm{CIGS}$ 용 후면전극으로서 낮은 전기저항성, 열팽창계수 및 기계적 특성이 우수하여 박막형 태양전지인 CIS/ $\mathrm{CIGS}$ 흡수층에서 생성된 전하의 이동전극으로 적 합한 재료로서 사용되고 있다 ${ }^{1-3)}$. Mo 박막은 스퍼 터링법에 의해 이중층으로 제조되는 것이 일반화된 증착방법이며 증착되는 공정압력과 인가전력에 의 해 전기적 특성의 변화가 크게 나타난다. 높은 $\mathrm{Ar}$ 분압에서 기판재와 밀착성을 높이기 위해 $\mathrm{Mo}$ 박막 을 증착하고 낮은 $\mathrm{Ar}$ 분압에서 낮은 전기저항성을 갖는 $\mathrm{Mo}$ 박막을 증착하고 있다4). 그러나 낮은 $\mathrm{Ar}$ 분압에서는 스퍼터링 일드의 감소로 인해 요구되는 박막의 두께를 형성하는데 많은 증착시간이 필요하다.

*Corresponding author. E-mail : plasma04@kitech.re.kr
CIGS 태양전지의 후면전극으로 증착되는 $\mathrm{Mo}$ 박 막의 전기전도성과 공정압력의 관계에 대한 타 연 구자들의 연구 ${ }^{4,6)}$ 에서 낮은 $\mathrm{Ar}$ 분압에서 증착되는 박막의 전도성이 결정립에 의한 영향을 많이 받는 다는 결과들을 보고하고 있다. Mo 박막의 전기저 항의 증가는 결정립계(결정립 크기), 불순물, 공극 및 박막의 성장구조에 의한 금속 내부의 결함이 원 인으로 사료된다.

$\mathrm{Mo}$ 박막의 대면적화와 고속증착공정을 개발함에 있어서 스퍼터링 일드를 높이고 더불어 낮은 전기 저항을 갖는 박막을 증착하기 위해서는 공정압력과 인가전력은 중요한 공정요인이었다. 스퍼터링 타겟 의 인가전력과 공정압력 변화를 조사한 예비실험 ${ }^{5}$ 을 통하여 전기저항이 증착공정의 압력조건에 따라 서 매우 변화하는 것을 알게 되어, 본 연구에서는 $\mathrm{Mo}$ 박막의 증착과정에서 공정압력에 따라 전기저 항의 급격히 변화하는 원인에 대해 고찰하고자 하 
였다.

이러한 조사를 위하여 Mo 박막을 $1.5 \mathrm{mTorr}$ 에서 $50 \mathrm{mTorr}$ 까지 변화를 주었으며 압력조건에 따라서 증착되는 박막의 표면형상, 성장구조, 불순물의 존 재여부 등을 조사함으로서 전기저항 변화에 주요하 게 미치는 인자가 무엇이었는지에 대한 결과를 보 고하고자 한다.

\section{2. 본 론}

\section{1 실험 방법}

$\mathrm{Mo}$ 박막은 $\mathrm{DC}$ 마그네트론 스퍼터링법으로 증착 하였으며, 시편은 전기저항 및 광특성분석 측정을 위하여 $\mathrm{Si}$ wafer $(25 \mathrm{~mm} \times 25 \mathrm{~mm})$ 를 사용하였다. 시 료의 장입 후 초기 배기진공을 $1.0 \times 10^{-5} \mathrm{Torr}$ 까지 배기하였으며 시료의 플라즈마 전세정으로 이온 에 칭은 $\mathrm{Ar}$ 가스를 인입하여 Uni-Polar Pulse 로 $-750 \mathrm{~V}$ 조건에서 20 분 동안 진행하였다.

스퍼터링법으로 $\mathrm{Mo}$ 박막을 증착할 때 증착공정 압력과 Mo 타겟에 인가되는 전력에 변화를 주었다. Mo target과 기판과의 거리는 $100 \mathrm{~mm}$ 로 하였으며, 스퍼터링되는 Mo 타겟의 면적은 $340 \mathrm{~mm} \times 70 \mathrm{~mm}$, Mo target의 인가전력은 $1.0 \mathrm{~kW}\left(4.1 \mathrm{~W} / \mathrm{cm}^{2}\right), 1.5 \mathrm{~kW}$ $\left(6.1 \mathrm{~W} / \mathrm{cm}^{2}\right), 2.0 \mathrm{~kW}\left(8.2 \mathrm{~W} / \mathrm{cm}^{2}\right)$ 로 하였다.

Mo 박막의 공정압력은 $1.0 \mathrm{mTorr}$ 에서 $50 \mathrm{mTorr}$ 조건까지 증착하였다. 각 공정 압력별 공정시간은 기초실험을 통하여 각각의 증착시간을 계산하여 약 $1 \mu \mathrm{m}$ 를 기준으로 금속 $\mathrm{Mo}$ 박막을 성막하였다.

같은 인가전력 $\left(8.2 \mathrm{~W} / \mathrm{cm}^{2}\right)$ 에서 공정압력변화 $(1$ mTorr $50 \mathrm{mTorr}$ )에 따른 전기저항측정 은 4-point probe (CMT-SR $1000 \mathrm{~N}$ )를 이용하였다. 증착변수에 대한 미세구조를 관찰하기 위해 XRD (X'pert-PRO,

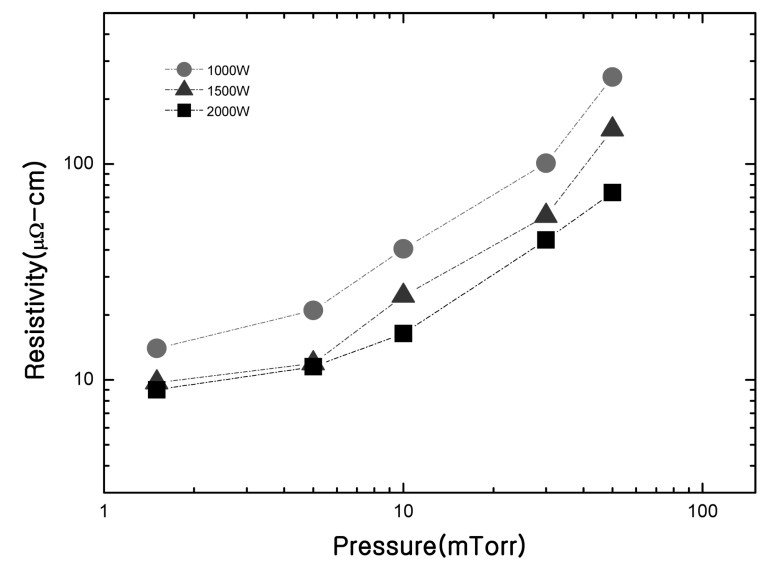

Fig. 1. electrical resistivity of Mo Thin films for various working pressures and target power; (a) XRD of the various working pressure at $2.0 \mathrm{~kW}$, (b) Grain size of Mo Thin films.
$\mathrm{Cuka}$ 선) 구조분석으로 Mo (110) 배향의 결정립 크 기를 조사하였으며 SEM (NOVA- NANO200) \& $\mathrm{AFM}$ 으로 표면형상을 관찰하였다. $\mathrm{Mo}$ 박막 내의 공극율을 알아보고자 광특성 분석방법으로 Spectroscopic Ellipsometry (SEMG-1000UV)를 이용하여 소광계수 $(\mathrm{k})$ 와 굴절률 $(\mathrm{n})$ 을 알아보았다. 마지막으로 XPS (thermo multilab 2000) 분석으로 Mo 박막의 결합에너지를 $\mathrm{Mo}$ 와 $\mathrm{MoO}_{\mathrm{x}}$ 으로 구분하여 $\mathrm{Mo}$ 와 산 화물 형성에 대해 조사하였다.

\section{2 실험 결과 및 고찰}

$\mathrm{Mo}$ 박막의 증착공정조건에 따른 전기저항에 대 한 결과를 그림 1에 나타내었다. 4-point probe으로 측정한 $\mathrm{Mo}$ 박막의 전기저항은 인가전력이 높을수 록 더 낮은 저항을 보였다. 인가 전력이 $4.1 \mathrm{~W} / \mathrm{cm}^{2}$, $6.1 \mathrm{~W} / \mathrm{cm}^{2}, 8.2 \mathrm{~W} / \mathrm{cm}^{2}$ 일 때 공정압력에 따른 결정 립 크기와 전기저항은 서로 상관관계가 있음을 확 인하였다. 특히, Mo 타겟 인가전력 $\left(8.2 \mathrm{~W} / \mathrm{cm}^{2}\right)$ 에서 $1.5 \mathrm{mTorr}$ 의 증착공정 압력조건에서 가장 낮은 9.0

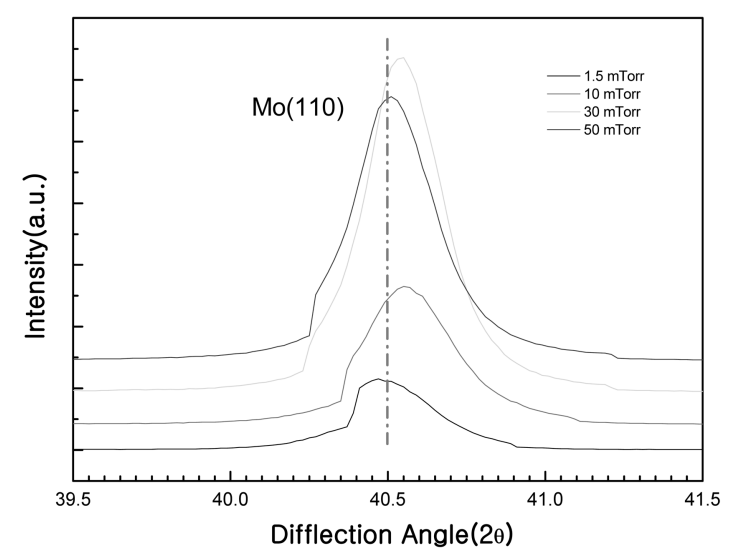

(a) XRD of the various working pressure at $2.0 \mathrm{~kW}$

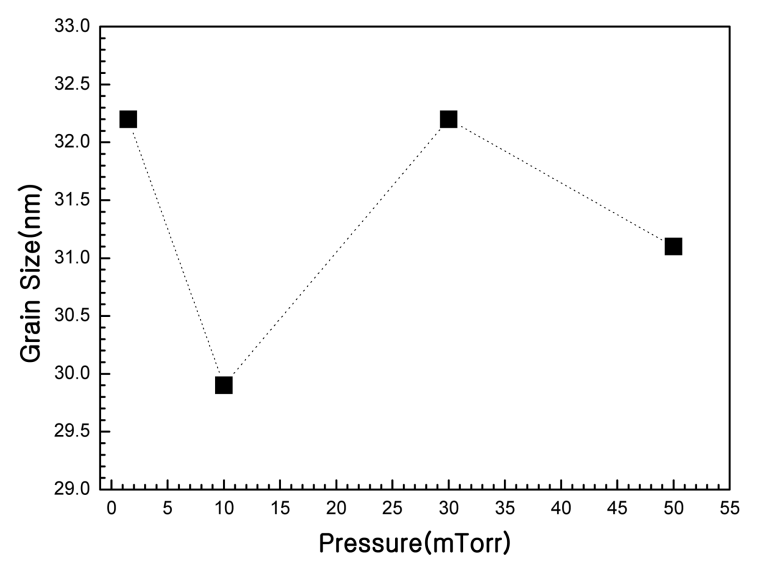

Fig. 2. Analysis of XRD for Mo thin films; (a) 1.5 mTorr, (b) $10 \mathrm{mTorr}$, (c) $50 \mathrm{mTorr}$, (d) $1.5 \mathrm{mTorr}$, (e) 10 mTorr, (f) 50 mTorr. 


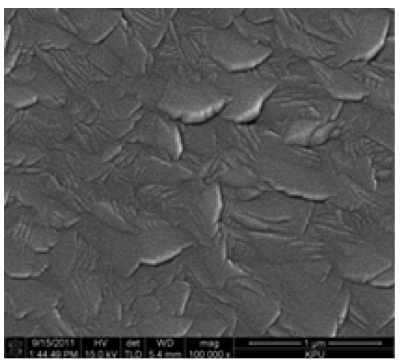

(a) 1.5 mTorr

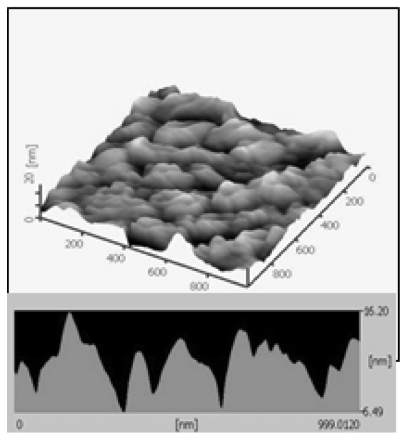

(d) 1.5 mTorr

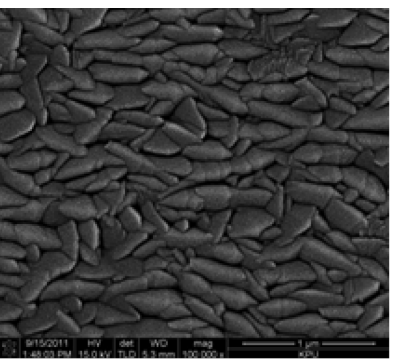

(b) 10 mTorr

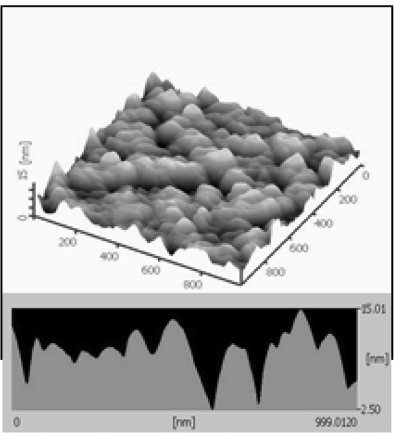

(e) 10 mTorr

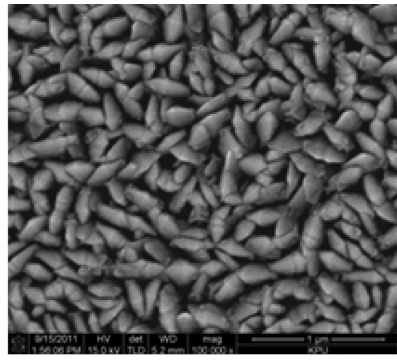

(c) $50 \mathrm{mTorr}$

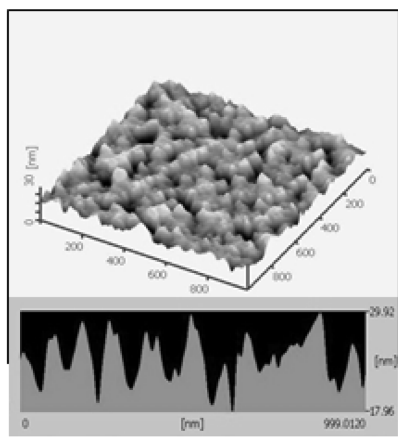

(f) $50 \mathrm{mT}$ orr

Fig. 3. Surface morphology of Mo Thin films ((a), (b), (c) are SEM images; (d), (e), (f) are AFM images).

$\mu \Omega-\mathrm{cm}$ 를 보였다. 공정압력의 증가에 따른 전기저 항의 변화에 대한 보곤)와 같이 증착공정 압력이 증가하면 전기저항이 증가하였다.

낮은 공정압력상태에서 증착한 $\mathrm{Mo}$ 박막의 저항 변화는 결정립의 크기와 매우 밀접한 관계를 보이 며 결정립이 클수록 저항은 감소한다. 이러한 결정 립의 영향을 살펴보기 위하여 타겟 인가전력을 8.2 $\mathrm{W} / \mathrm{cm}^{2}$ 으로 한 Mo 박막에 대해 X-ray 를 $30^{\circ} \sim 50^{\circ}$ 까지 조사하여 공정압력의 변화에 대한 $\mathrm{Mo}$ 박막의 스펙트럼을 그림 2(a)에 나타내었고, Scherrer 식을 이용하여 Mo (110) 피크에 대해 회절각도와 반각 폭을 측정하여 결정립 크기를 계산하여 결과를 그 림 2(b)에 나타내었다.

그림 2의 전기저항의 변화폭에 대해 살펴보면 타 겟 인가전력의 변화에 대해서 인가전력이 높을수록 전기저항이 낮아졌다. 그리고 동일한 인가전력 하 에서 공정압력의 변화에 의해서 매우 급격하게 전 기저항이 증가하는 것을 알 수 있다. $\mathrm{Ar}$ 분압이 10 mTorr보다 낮은 상태에서의 증가폭과 대비하여 높 은 $\mathrm{Ar}$ 분압상태에서 증착된 $\mathrm{Mo}$ 박막의 전기저항 증가폭이 현저하였다. 그러나 공정압력의 변화에 따 라 결정립 크기와 전기 저항은 크게 관계되지 않았다.

이러한 결과로서 결정립 크기의 증감에 의한 전 기저항의 변화 원인은 결정립 크기보다 박막 성장 과정의 성장구조와 박막의 결함, 불순물에 의한 영 향이 전기저항에 미치는 더 중요한 인자로 판단하 였다.
박막의 성장과정에 대한 조사로 Mo 박막 표면형 상을 $\mathrm{AFM}$ 과 $\mathrm{SEM}$ 으로 관찰하였고 엘립소메트리를 이용한 광학분석을 통해 박막의 공극율 조사 및 XPS 를 통한 Mo 박막의 결합구조 분석으로 전기저항에 미치는 인자를 찾고자 하였다.

그림 3(a), (b), (c), (d)는 $\mathrm{SEM}$ 으로 관찰한 $\mathrm{Mo}$ 박막의 표면형상 이미지로 인가전력이 $8.2 \mathrm{~W} / \mathrm{cm}^{2}$ 일 때, $1.5 \mathrm{mTorr}$ 와 $50 \mathrm{mTorr}$ 의 두 공정에 대해서 보여 주고 있다. $50 \mathrm{mTorr}$ 공정압력에서 증착된 $\mathrm{Mo}$ 박 막은 주상정구조로 성장하여 표면에 작은 결정들이 모여있는 형상을 나타내었고, $1.5 \mathrm{mTorr}$ 공정압력에 서는 촘촘히 배열된 섬유질상의 조직구조로 성장한 큰 결정 형상으로 표면이 둥근 돔 형태를 나타내었 다. $\mathrm{AFM}$ 으로 박막 표면의 거칠기를 조사한 그림 3(e), (f)와 같이 $50 \mathrm{mTorr}$ 공정압력에서 표면 거칠 기값은 $2.5 \mathrm{~nm}$ 이었고 표면에 작은 돌기들이 형성되 었고 $1.5 \mathrm{mTorr}$ 공정압력에서는 $3.7 \mathrm{~nm}$ 로 측정되어 돌기들의 크기가 증가하는 것을 알 수 있었다.

$\mathrm{SEM}$ 과 $\mathrm{AFM}$ 결과로 공정압력의 변화폭을 넓게 하여 증착한 Mo 박막의 성장구조가 Thornton의 박 막 성장메카니즘의 Zone 모델에 근사하는 것으로 사료된다. 고진공 영역에서는 기판에 도달하는 많 은 입자들의 높은 충격에너지로 인해 원자 피닝 효 과가 증가함으로서 섬유질상의 조직구조를 갖는 조 밀한 Mo 박막이 Zone T 구간에서 성장하게 된다. 반면에 저진공 영역에서는 결정성장이 다공성의 주 상정 조직구조를 갖는 Zone 1 구간에서 성장하게 


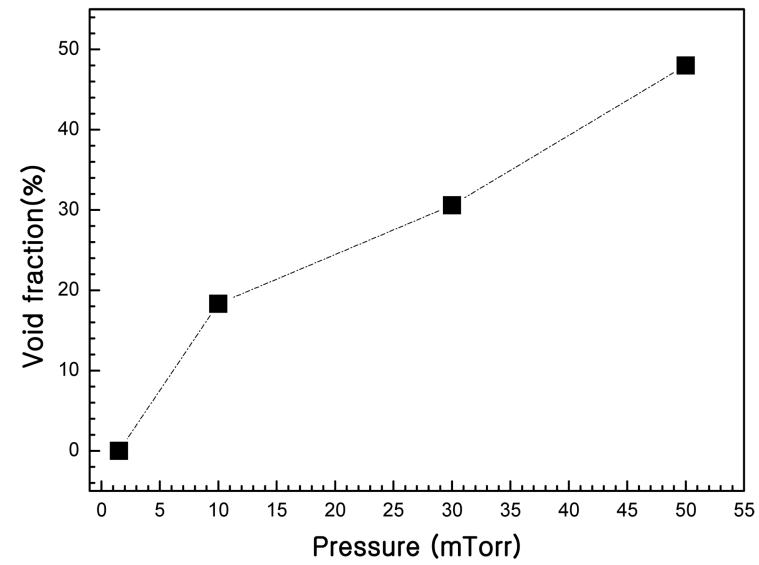

Fig. 4. Void fraction of Mo thin films (The various working pressure at $2.0 \mathrm{~kW}$ ); (a) $1.5 \mathrm{mTorr}$, (b) 50 mTorr.

된다.

실험 결과에서 높은 $\mathrm{Ar}$ 분압영역에서 증착되는 주상정구조의 $\mathrm{Mo}$ 박막은 전기저항이 매우 높고, 낮 은 $\mathrm{Ar}$ 분압에서 증착된 섬유질상의 서로 엉켜있는 구조의 Mo 박막은 저항이 낮았다. 따라서 박막의 성장구조가 전기저항과 매우 밀접한 관계가 있음을 알 수 있었다.

스퍼터링법에 의해 증착된 박막은 성장과정에서 형성되는 핀홀과 미세공극의 생성과 산소와의 친화 력이 매우 높은 Mo 박막이 표면 원자와의 반응을 통하여 산화물을 형성 4,7-9)하고 이러한 공극과 산화 물의 분포정도에 따라서 박막의 저항이 바뀌는 것 으로 판단되어 Spectroscopic ellipsometry (SE)를 통 한 공극율 조사와 XPS를 통한 Mo 박막의 결합구 조를 조사하였다.

인가전력이 $8.2 \mathrm{~W} / \mathrm{cm}^{2}(2.0 \mathrm{~kW})$ 에서 공정압력에 따 른 박막 내의 공극 형성에 대해 $\mathrm{SE}$ 광특성분석으 로 박막의 굴절률 $(\mathrm{n})$ 과 소광계수 $(\mathrm{k})$ 을 $633 \mathrm{~nm}$ 파장 에서 측정하였다 ${ }^{6,10)}$. 박막의 굴절율과 소광계수의 측정값을 통해 공정압력의 변화에 대한 공극율을 계산하였고, 그 결과를 그림 4에 나타내었다.

공극율의 계산과정에서 산소친화력이 높은 $\mathrm{Mo}$ 표면원자와 산소와의 결합이 있으나 광분석과정에 서 산화물의 유무에 따른 굴절율의 변화보다 박막 의 공극에 따라서 광특성변화가 더 크다고 판단하 여 산화물에 대한 변화는 고려하지 않았다.

공정압력이 증가하면 굴절율과 소광계수는 감소 하는 경향을 보였으며 굴절율의 감소가 의미하는 것은 박막 내의 밀도가 작아져 나타나는 현상으로 사료된다. 먼저, $1.5 \mathrm{mTorr}$ 의 공정압력을 기준으로 박막 내의 공극율은 단위면적당 비어있는 상태를 $0 \%$ 로 가정하여 압력 변화에 따른 공극율을 계산하

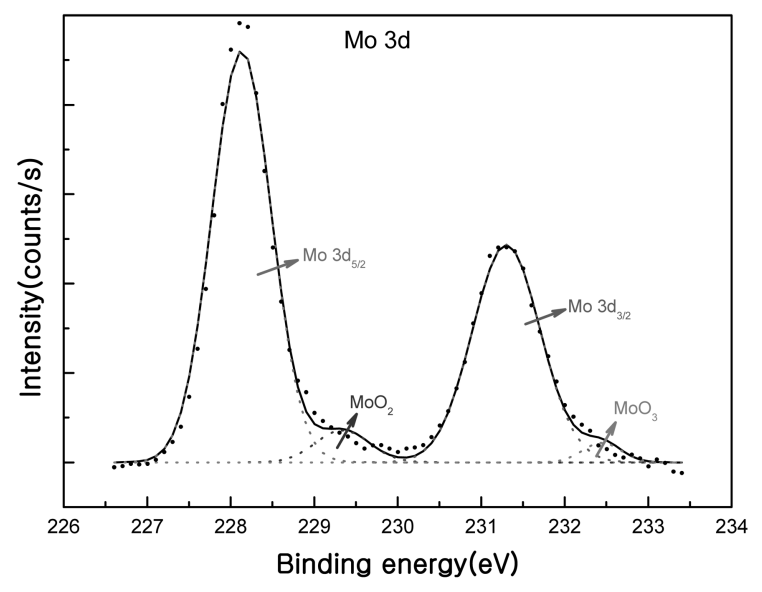

(a) 1.5 mTorr

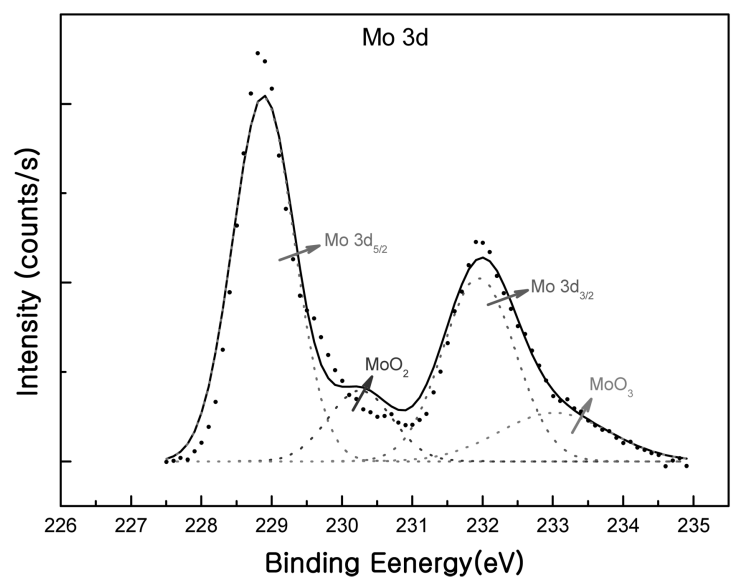

Fig. 5. The Gaussian fitting of Mo 3d peaks.

였다. 그리고 $50 \mathrm{mTorr}$ 의 공정압력에서 단위면적 당 비어있는 공극율은 최대 $48 \%$ 를 얻었다. 그러므 로 박막의 표면으로부터 불순물이 결합할 수 있는 확률은 공정압력의 증가에 따라 높아지는 것을 의 미하게 된다.

Mo 박막의 표면을 XPS 분석으로 Mo 산화물 생 성에 대한 결과를 그림 5 에 나타내었다. $\mathrm{Mo}$ 는 $3 \mathrm{~d}_{5 / 2}$ 와 $3 \mathrm{~d}_{3 / 2}$ 구조의 결합에너지는 각각 $228.0 \mathrm{eV}$ 와 231.0 $\mathrm{eV}$ 를 보인다, ${ }^{3,11-14)}$. 인가전력이 $8.2 \mathrm{~W} / \mathrm{cm}^{2}$ 에서 1.5 mTorr 압력에서 증착된 Mo 박막에 대해 측정된 결 합에너지는 $3 \mathrm{~d}_{5 / 2}$ 는 $228.13 \mathrm{eV}, 3 \mathrm{~d}_{3 / 2}$ 은 $231.32 \mathrm{eV}$ 를 나타내었다.

그림 5(a)와 (b)에서는 Mo 피크에 대해서 Gaussian 피팅하여 분석한 결과이고 $1.5 \mathrm{mTorr}$ 에서 증착된 $\mathrm{Mo}$ 박막에서 순수 $\mathrm{Mo}$ 와 chemical shift된 Mo 산화 물인 $\mathrm{MoO}_{2}(229.35 \mathrm{eV})$ 와 $\mathrm{MoO}_{3}(232.45 \mathrm{eV})$ 가 1.0 $1.2 \mathrm{eV}$ 이동되어 관측되었다. $\mathrm{Mo}, \mathrm{MoO}_{2}, \mathrm{MoO}_{3}$ 의 피크를 피팅하여 각 피크의 면적을 계산하였고 $\mathrm{Mo}$ 박막의 산화물 비율은 $4.2 \%$ 와 $1.8 \%$ 를 나타내었다 


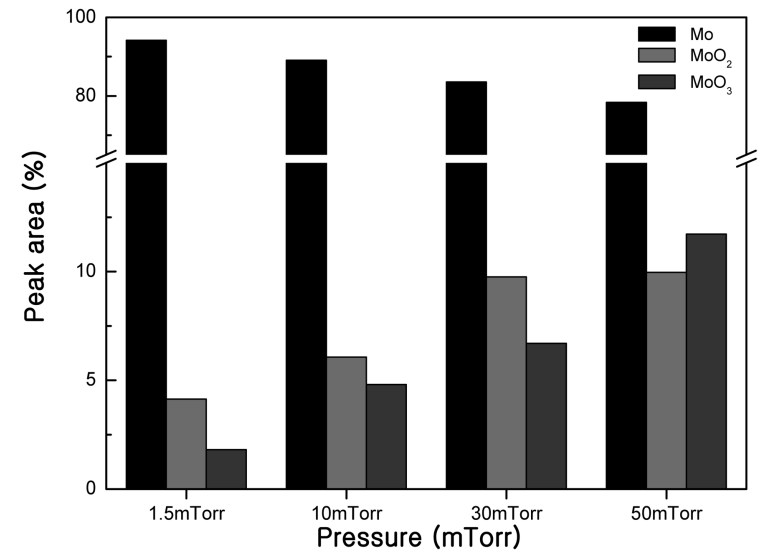

Fig 6. The comparison of Mo and Mo-oxide peak areas for Mo thin films.

(그림 6). 그림 5(b)는 공정압력이 $50 \mathrm{mTorr}$ 에서 $\mathrm{Mo}$ $3 \mathrm{~d}_{5 / 2}(228.88 \mathrm{eV}), 3 \mathrm{~d}_{3 / 2}(231.94 \mathrm{eV})$ 의 결합에너지를 나 타냈으며, $\mathrm{MoO}_{2}(230.25 \mathrm{eV})$ 와 $\mathrm{MoO}_{3}(233.01 \mathrm{eV})$ 로 이동되어 나타났다.

피크분석을 통하여 $\mathrm{Mo}$ 박막 내의 $\mathrm{MoO}_{2}$ 와 $\mathrm{MoO}_{3}$ 의 불순물 비율이 $9.9 \%$ 와 $11.7 \%$ 로 증가하였음을 알 수 있었다. 그림 6에서 공정압력이 $1.5 \mathrm{mTorr}$ 에 서 $50 \mathrm{mTorr}$ 로 증가하면 $\mathrm{MoO}_{2}, \mathrm{MoO}_{3}$ 의 불순물 비 율이 증가함을 보였다.

공정압력의 증가에 따른 산화물의 증가는 $\mathrm{Mo}$ 박 막의 성장구조의 변화, 공극율의 증가와 관련이 있 으며, $\mathrm{SEM}$ 과 $\mathrm{AFM}$ 의 결과들과 잘 일치하고 있다. 즉, $8.2 \mathrm{~W} / \mathrm{cm}^{2}$ 인가전력에서 공정압력에 따른 전기 저항의 증가는 결정립 크기보다 $\mathrm{Mo}$ 박막의 표면 형상과 성장구조 변화에 의해 박막의 공극율 및 산 화물의 분포가 전기저항을 증가시키는 원인으로 판 단된다.

\section{3. 결 론}

$\mathrm{Mo}$ 박막의 증착에서 공정압력에 따른 전기저항 의 변화에 대해서 조사하였다. 공정압력의 증가에 따라서 저항의 증가율은 매우 급격히 변화하였다. $\mathrm{Mo}$ 박막의 전기저항은 공정압력이 $1 \mathrm{mTorr}$ 에서 10 $\mathrm{mTorr}$ 까지는 크게 변화가 없다가 $10 \mathrm{mTorr}$ 이상이 되면 저항이 매우 증가하였다. Mo 박막과 저항의 관계에서 결정립 크기에 의한 영향은 크게 받지 않 았으며, 박막의 성장구조와 박막의 공극율이 매우
밀접한 관계가 있음이 조사되었다. 결론으로 타겟 인가전력 $\left(8.2 \mathrm{~W} / \mathrm{cm}^{2}\right)$ 과 $1.5 \mathrm{mTorr}$ 의 공정압력에서 증 착한 $\mathrm{Mo}$ 박막에서 가장 낮은 $9.0 \mu \Omega-\mathrm{cm}$ 의 전기저 항을 보였으며, 결정성장구조가 치밀하고 증착과정 에서 형성되는 공극이 적은 $\mathrm{Mo}$ 박막의 전기저항이 낮게 나타났다.

\section{참고문헌}

1. A. Rockett, K. Granath, S. Asher, M. M. Al Jassim, F. Hansoon, R. Matson, B. Basol, V. Kapur, J. S. Britt, T. Gillespie, C. Marshall, Solar Energy Mater. Solar Cells, 59 (1999) 255.

2. N. G. Dhere, V. S. Gade, A. A. Kadam, A. H. Jahagirdar, S. S. Kulkarni, S. M. Bet, Mater. Sci. Eng. B, 116 (2005) 303.

3. L. Assmann, J. C. Bernède, A. Drici, C. Amory, E. Halgand, M. Morsli, Appl. Surf. Sci. 246 (2005) 159.

4. J. H. Scofield, A. Duda, D. Albin, B. L. Ballardb, P. K. Predeckib, Thin Solid Films, 260 (1995) 26.

5. 조용기, 김강삼, 송영식, 임태홍, 생산기술연구논문 집. 23 (2011) 221.

6. J.-H. Yoon, S. H. Cho, W. M. Kim, J.-K. Park, Y.-J. Baik, T. S. Lee, T.-Y. Seong, J.-H. Jeong, Solar Energy Mater. Solar Cells, 95 (2011) 2959.

7. T. Yamaguchi, R. Miyagawa, Jpn. J. Appl. Phys. 30 (9A) (1991) 2069.

8. I. Blech, U. Cohen. J. Appl. Phys. 53 (1982) 4202.

9. H. Windischmann. R. W. Collins, J. M. Cavese, J. Non-Crystalline Solids, 85 (1986) 261.

10 S. Y. Kim, J. Optical Soc. Korea (Korean Ed), 1 (1990) 73.

11. M. Bodegard, K. Granath, L. Stolt, A. Rockett, Solar Energy Mater. Solar Cells, 58 (1999) 199.

12. B. Canava, J. Vigneron, A. Etcheberry, D. Guimard, J.-F. Guillemoles, D. Lincot, S. O. S. Hamatly, Z. Djebbour, D. Mencaraglia, Thin Solid Films, 431432 (2003) 289.

13. B. Canava, J. Vigneron, A. Etcheberry, D. Guimard, P. P. Grand, J.-F. Guillemoles, D. Lincot, S. O. S. Hamatly, Z. Djebbour, D. Mencaraglia, Thin Solid Films, 403-404 (2002) 425.

14. K. Granath, L. Stold, M. Bodegerd, A. Rockett, D. Schroeder, n: Proceedings of the 14th European Photovoltaic Solar Energy Conference, Barcelona, 1997, p.1278-1282. 